\title{
Studies of the Cyclopolymerization in the Presence of Alkylaluminum Chlorides. I. Polymerization of o-Allylphenyl Acrylate
}

\author{
Kazuaki YoKota, Nobuhiro Hirayama, and Yoshiyuki Takada \\ Department of Chemical Process Engineering, Faculty \\ of Engineering, Hokkaido University, Sapporo, Japan.
}

(Received May 23, 1975)

\begin{abstract}
The addition of complexing agents, alkylaluminum chlorides, to oallylphenyl acrylate has been reported to cause an increase in its cyclopolymerization tendency. For the polymerization in the presence of $\mathrm{AlEt}_{2} \mathrm{Cl}$, the extent of cyclization was larger than that for the conventional radical polymerization. The increase in the extent of cyclization was attributed to the action of $\mathrm{AlEt}_{2} \mathrm{Cl}$, by which the side reaction producing residual double bonds was depressed. In the presence of $\mathrm{AlEt}_{1.5} \mathrm{Cl}_{1.5}$ and $\mathrm{AlEtCl}{ }_{2}$ the extent of cyclization and the rate of polymerization were far larger than those in the case of $\mathrm{AlEt}_{2} \mathrm{Cl}$. At an $\mathrm{Al} / \mathrm{M}$ molar ratio of 1.0 or above, the extent of cyclization increased to $93-97 \%$. The results suggested that there would be an intramolecular interaction between the acrylic double bond and the allylic double bond.

KEY WORDS o-Allylphenyl Acrylate / Cyclopolymerization / Radical Polymerization / Diethylaluminum Chloride / Ethylaluminum Sesquichloride / Ethylaluminum Dichloride / Cyclization Constant / Intramolecular Interaction / Cyclic Structure /
\end{abstract}

It has been reported by Solomon, et al., ${ }^{1-3}$ that the polymerization of $o$-allylphenyl acrylate, an unsymmetrical bifunctional monomer, proceeds exclusively or predominantly through acrylic double bonds with radical, anionic, and coordination catalysts. Until recently, however, little attention was given to the cyclopolymerization. o-Allylphenyl acrylate contains an electropositive and an electronegative double bond in the molecule. The complexation of an electron acceptor monomer such as methyl methacrylate with a Lewis acid, which converts this monomer into a strong electron acceptor, causes an intermolecular interaction with an electron donor monomer such as styrene, thus giving an equimolar alternating copolymer. ${ }^{4-6}$ If $o$-allylphenyl acrylate has an analogous intramolecular interaction when polymerized in the presence of a complexing agent, this may lead to a strong increase in the extent of cyclization. Therefore, it is interesting to see how complexing agents affect the intramolecular cyclization in comparison with the alternating copolymerization. In the present paper the authors report the results of an investigation of the influence of com- plexing agents, alkylaluminum chlorides, upon the cyclopolymerization.

\section{EXPERIMENTAL}

\section{Reagents}

Monomers. o-Allylphenyl acrylate was obtained from acryloyl chloride and o-allylphenol.

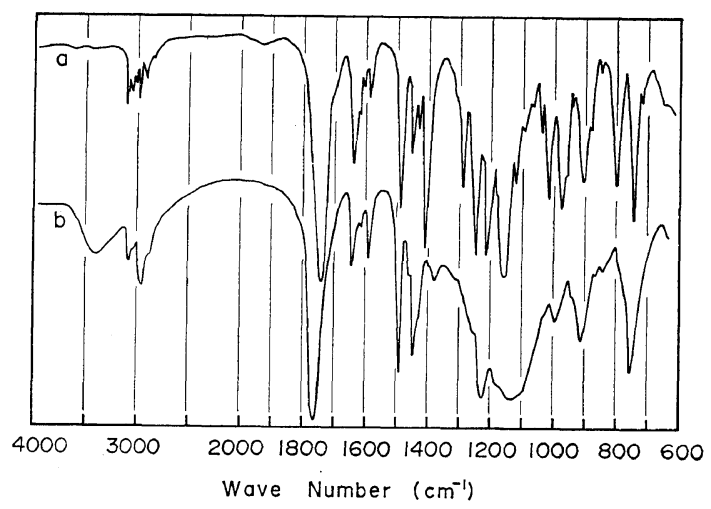

Figure 1. IR spectra of (a) $o$-allylphenyl acrylate and (b) its polymer obtained with AIBN at $60^{\circ} \mathrm{C}$, $f_{c}=0.3$. 


\section{K. Yokota, N. Hirayama, and Y. TAKada}

The fraction boiling at $107-108^{\circ} \mathrm{C}(3 \mathrm{~mm})$ was collected: $n_{\mathrm{D}}^{25} 1.5201$ [lit. $^{1}$ bp $88-90^{\circ} \mathrm{C}(0.9 \mathrm{~mm})$, $\left.n_{\mathrm{D}}^{20} 1.5225\right] ; d_{4}^{15} 1.0403$. The IR spectrum is shown in Figure 1. o-Methoxyallylbenzene was prepared from O-methylation of $o$-allylphenol by dimethyl sulfate. Methyl acrylate and styrene were commercially obtained.

Alkylaluminum Chlorides. Diethylaluminum chloride, ethylaluminum sesquichloride, and ethylaluminum dichloride were prepared from triethylaluminum and aluminum trichloride by the conventional method, distilled under nitrogen atmosphere, and diluted into purified toluene.

Solvent. Toluene was of reagent grade and was purified by the ordinary method.

\section{Polymerization}

All polymerizations were carried out in sidearmed ampoules. The solvent and monomers were charged into the ampoules previously equipped with a serum stopper cap at the side arm. The ampoules were evacuated and sealed. The alkylaluminum chloride solution was added by a syringe through serum cap. Polymerizations were achieved in thermostated baths without agitation

For the polymerization of $o$-allylphenyl acrylate in the presence of $\mathrm{AlEt}_{2} \mathrm{Cl}$ the reaction system was homogeneous, but a precipitate separated in the case of the formation of polymers with a high extent of cyclization. In the presence of $\mathrm{AlEt}_{1.5} \mathrm{Cl}_{1.5}$ the reaction mixture turned into a turbid solution within a few minutes, and then a somewhat sticky precipitate appeared. In the presence of $\mathrm{AlEtCl}_{2}$, a slurry precipitate formed as the reaction progressed.

At the end of the polymerization, the reaction mixture was poured into a large amount of methanol containing hydrochloric acid, the precipitate produced in the reaction steps was decomposed with methanol, and a white solid polymer was separated. The polymers with a high extent of cyclization were insoluble in benzene, but soluble in tetrachloroethane and nitrobenzene, although a portion of the polymers obtained at high conversion was insoluble in the organic solvents.

\section{Analysis}

Determination of the Extent of Cyclization in Polymers. For determination of the extent of cyclization, a calibration curve was made by plotting the mole fraction of the residual double bonds versus $D_{920} / D_{1495}$, where $D_{920} / D_{1495}$ is the ratio of the optical densities measured at 920 and $1495 \mathrm{~cm}^{-1}$. The amount of residual double bonds was determined according to the elementary analysis for bromine in the polymers which resulted when the olefin was allowed to react with bromine in carbon tetrachloride for $30 \mathrm{~min}$; here the Schöniger $\operatorname{method}^{7}$ was used. For carbon tetrachloride-insoluble polymers the extent of cyclization was estimated by extrapolating the calibration curve.

Determination of the Composition and Residual Double Bonds in Copolymers. The composition and residual double bonds in copolymers were determined from the relative area of the absorptions in the NMR spectrum.

Determination of the Cyclic Structure of the Polymers Obtained in the Presence of Alkylaluminum Chlorides. The cyclic structure of the polymers was determined by analysis of the IR spectra of the materials obtained by the following procedure: The polymers were hydrolyzed with 10-\% methanolic potassium hydroxide, and then the hydrolyzed polymers were treated with diazomethane according to the method used for poly(methacrylic ester)s. ${ }^{8}$ By this treatment the esterification of acids and the methylation of phenols took place in the hydrolyzed polymers at the same time.

\section{RESULTS AND DISCUSSION}

Radical Polymerization of o-Allylphenyl Acrylate The polymerization results are given in Table I. The radical polymerization even in

Table I. Radical polymerization of $o$-allylphenyl acrylate ${ }^{a}$

\begin{tabular}{ccccc}
$\begin{array}{c}\text { [M], } \\
\text { mol } l^{-1}\end{array}$ & $\begin{array}{c}\text { [AIBN], } \\
\mathrm{mol} l^{-1}\end{array}$ & $\begin{array}{c}\text { Time, } \\
\mathrm{hr}\end{array}$ & $\begin{array}{c}\text { Conversion, } \\
\%\end{array}$ & $\begin{array}{c}\text { Extent of } \\
\text { cyclization, \% }\end{array}$ \\
\hline $\begin{array}{c}5.53 \\
(\text { Bulk) }\end{array}$ & 0.014 & 4 & 4.9 & 19.0 \\
3.26 & 0.012 & 5 & 7.8 & 27.0 \\
2.48 & 0.011 & 6 & 9.7 & 29.6 \\
1.58 & 0.011 & 7 & 8.7 & 36.1 \\
1.14 & 0.009 & 8 & 12.8 & 40.3 \\
0.54 & 0.011 & 12 & 16.1 & 50.8 \\
\hline
\end{tabular}

a Solvent, toluene; temp, $60^{\circ} \mathrm{C}$. 


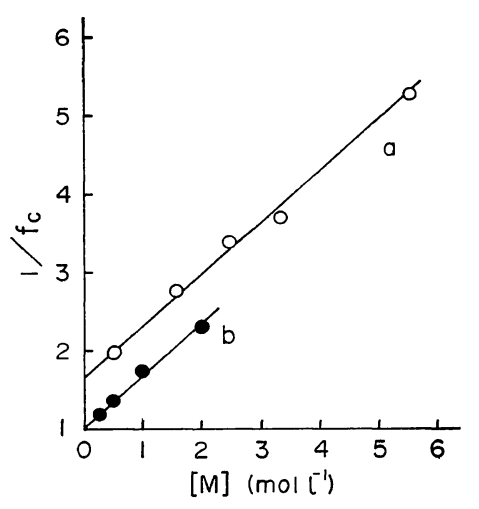

Figure 2. Representation of the experimental data according to eq 1: (a) with AIBN at $60^{\circ} \mathrm{C}$; (b) in the presence of $\mathrm{AlEt}_{2} \mathrm{Cl}$ at $40^{\circ} \mathrm{C}, A l / M 0.2$.

bulk at $60^{\circ} \mathrm{C}$ was not accompanied by gelation at below $30 . \%$ conversion. The IR spectrum of a polymer obtained is shown in Figure 1. IR spectral analysis shows that the polymer contains a large degree of residual double bonds. The residual double bond is in the form of a pendant allylic double bond, as indicated in the IR spectrum by the absorptions at 920 and 1000 $\mathrm{cm}^{-1}$. The formation of soluble polymers in the above reactions suggests that the polymerization proceeds according to a cyclopolymerization mechanism. In Table I the extent of cyclization increases with a decrease in the monomer concentration, as is generally found in cyclopolymerization. Between the fraction of cyclized units $f_{\mathrm{c}}$, which is the extent of cyclization presented by a mole fraction, and the monomer concentration $[\mathrm{M}]$ the following relationship holds: ${ }^{9}$

$$
\frac{1}{f_{\mathrm{c}}}=1+\frac{k_{\mathrm{p}}}{k_{\mathrm{c}}}[\mathrm{M}]
$$

where $k_{\mathrm{p}}$ and $k_{\mathrm{c}}$ are the velocity constants of the intermolecular linear propagation and the intramolecular cyclization, respectively. In Figure 2 the experimental data of Table I are plotted according to eq 1. A good straight line is found; the slope gives $k_{\mathrm{p}} / k_{\mathrm{c}}=0.67$. However the extrapolated value of the intercept fails to pass through 1.0. This discrepancy is interpreted as being caused by some participation of the side reaction which would give the corresponding amount of pendant double bonds to the polymer: for example, the intramolecular chain transfer to the allyl group which can be expressed by eq 2 .<smiles>C=CCc1ccccc1OC(=O)[CH]C</smiles><smiles>C=CC(CCC)Oc1ccccc1C(=O)CC</smiles>

Polymerization of o-Allylphenyl Acrylate in the Presence of $\mathrm{AlEt}_{2} \mathrm{Cl}$

The effect of the $\mathrm{AlEt}_{2} \mathrm{Cl}$ molar content in the reaction system is shown in Table II. Spontaneous polymerization, i.e., in the absence of a free radical initiator, occurred in the presence of $\mathrm{AlEt}_{2} \mathrm{Cl}$. The addition of a radical initiator caused a moderate increase in the rate of polymerization at $40^{\circ} \mathrm{C}$. When the molar ratio of $\mathrm{AlEt}_{2} \mathrm{Cl}$ to the monomer $(A l / M)$ reached 0.3, the rate of polymerization attained a maximum and the extent of cyclization increased to $77.5 \%$. At an Al/M molar ration of 1.0 the yield of polymers sharply decreased. Table III shows that the extent of cyclization is almost uninfluenced by changes in polymerization temperature. In

Table II. Polymerization of $o$-allylphenyl acrylate in the presence of $\mathrm{AlEt}_{2} \mathrm{Cl}^{\mathrm{a}}$

\begin{tabular}{|c|c|c|c|c|}
\hline $\begin{array}{l}\text { [AIBN], } \\
\text { mmol } l^{-}\end{array}$ & $\begin{array}{c}A l / M, \\
\text { Molar ratio }\end{array}$ & $\begin{array}{l}\text { Time } \\
\mathrm{hr}\end{array}$ & $\begin{array}{c}\text { Conversion } \\
\%\end{array}$ & $\begin{array}{l}\text { Extent of } \\
\text { cyclization, } \%\end{array}$ \\
\hline \multirow[t]{2}{*}{0} & 0.3 & 24 & 3.4 & 56.0 \\
\hline & 1.0 & 24 & 0 & - \\
\hline \multirow[t]{6}{*}{6.12} & 0.05 & 6 & 1.8 & 48.5 \\
\hline & 0.2 & 6 & 24.9 & 77.5 \\
\hline & 0.3 & 6 & 36.2 & 76.5 \\
\hline & 0.4 & 6 & 30.1 & 73.5 \\
\hline & 0.5 & 6 & 28.2 & 74.5 \\
\hline & 1.0 & 6 & 5.8 & 65.0 \\
\hline
\end{tabular}

a Solvent, toluene; $[\mathrm{M}], 0.51 \mathrm{~mol} l^{-1}$; temp, $40^{\circ} \mathrm{C}$. 
Table III. Effect of temperature on the polymerization of $o$-allylphenyl acrylate in the presence of $\mathrm{AlEt}_{2} \mathrm{Cl}^{\mathrm{a}}$

\begin{tabular}{rcc}
\hline $\begin{array}{r}\text { Temp } \\
{ }^{\circ} \mathrm{C}\end{array}$ & $\begin{array}{c}\text { Conversion, } \\
\%\end{array}$ & $\begin{array}{c}\text { Extent of } \\
\text { cyclization, } \%\end{array}$ \\
\hline 0 & 7.1 & 64.5 \\
30 & 20.1 & 70.0 \\
40 & 36.1 & 75.5 \\
50 & 63.4 & 75.5 \\
60 & 74.1 & 79.5 \\
\hline
\end{tabular}

a Solvent, toluene; $[\mathrm{M}], 0.51 \mathrm{~mol} l^{-1}$; [AIBN], 6.12 $\mathrm{mmol} l^{-1} ; A l / M$ molar ratio, 0.3 ; time, $6 \mathrm{hr}$.

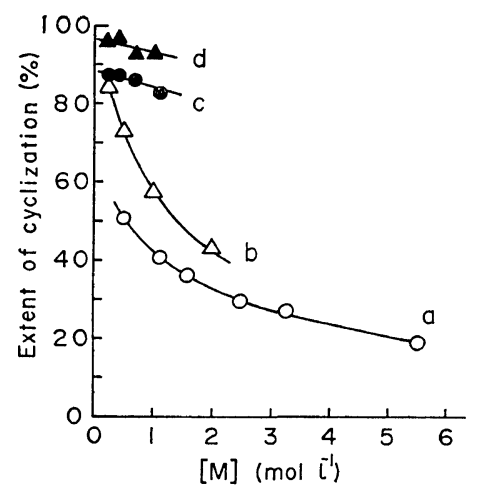

Figure 3. Effect of monomer concentration upon the extent of cyclization on the polymerizations: (a) with AIBN at $60^{\circ} \mathrm{C}$; (b) in the presence of $\mathrm{AlEt}_{2} \mathrm{Cl}$ at $40^{\circ} \mathrm{C}, A l / M 0.2$; (c) in the presence of $\mathrm{AlEt}_{1.5} \mathrm{Cl}_{1.5}$ at $40^{\circ} \mathrm{C}, A l / M$ 1.0; (d) in the presence of $\mathrm{AlEtCl}_{2}$ at $40^{\circ} \mathrm{C}, A l / M$ 1.0.

Figure 3 the extent of cyclization indicates the dependence on monomer concentration. As shown in Figure 2, the experimental data are well fitted by a straight line when plotted according to eq 1 . The slope gives $k_{\mathrm{p}} / k_{\mathrm{c}}=0.62$, which is in fair accord with the value of the conventional radical polymerization shown above. Consequently the increase in the extent of cyclization is attributed to the action of $\mathrm{AlEt}_{2} \mathrm{Cl}$ by which the side reaction, as expressed by eq 2 , is depressed.

Polymerization of 0 -Allylphenyl Acrylate in the Presence of $\mathrm{AlEt}_{1.5} \mathrm{Cl}_{1.5}$

The effect of $\mathrm{AlEt}_{1.5} \mathrm{Cl}_{1.5}$ molar content is shown in Table IV. In the presence of $\mathrm{AlEt}_{1.5} \mathrm{Cl}_{1.5}$ the rate of polymerization and the extent of cyclization were far larger than those in the case
Table IV. Polymerization of $o$-allylphenyl acrylate in the presence of $\mathrm{AlEt}_{1.5} \mathrm{Cl}_{1.5}{ }^{\mathrm{a}}$

\begin{tabular}{|c|c|c|c|c|}
\hline $\begin{array}{l}\text { [AIBN], } \\
\text { mmol } l^{-1}\end{array}$ & $\begin{array}{c}A l / M, \\
\text { Molar ratio }\end{array}$ & Time, & Conversion, & $\begin{array}{l}\text { Extent of } \\
\text { cyclization, } \%\end{array}$ \\
\hline \multirow[t]{8}{*}{0} & 0.25 & 3 & 4.1 & 80.5 \\
\hline & 0.5 & 3 & 5.4 & 85.0 \\
\hline & 0.75 & 3 & 10.8 & 81.5 \\
\hline & 1.0 & 3 & 12.0 & 89.0 \\
\hline & 1.25 & 3 & 16.3 & 91.0 \\
\hline & 1.5 & 3 & 19.6 & 89.0 \\
\hline & 1.75 & 3 & 23.2 & 91.5 \\
\hline & 2.0 & 3 & 23.3 & 93.0 \\
\hline \multirow[t]{4}{*}{5.38} & 0.07 & 0.5 & 1.9 & 73.5 \\
\hline & 0.2 & 0.5 & 18.1 & 83.0 \\
\hline & 0.6 & 0.5 & 58.4 & 83.5 \\
\hline & 1.0 & 0.5 & 70.6 & 85.5 \\
\hline
\end{tabular}

a Solvent, toluene; $[\mathrm{M}], 0.48 \mathrm{~mol} l^{-1}$; temp, $40^{\circ} \mathrm{C}$.

Table V. Effect of temperature on the polymerization of $o$-allylphenyl acrylate in the presence of $\mathrm{AlEt}_{1.5} \mathrm{Cl}_{1.5}{ }^{\mathrm{a}}$

\begin{tabular}{crrrr}
\hline $\begin{array}{c}\text { [AIBN], } \\
\text { mmol } l^{-1}\end{array}$ & $\begin{array}{c}\text { Temp, } \\
{ }^{\circ} \mathrm{C}\end{array}$ & $\begin{array}{c}\text { Time, } \\
\mathrm{hr}\end{array}$ & $\begin{array}{r}\text { Conversion, } \\
\%\end{array}$ & $\begin{array}{c}\text { Extent of } \\
\text { cyclization, } \%\end{array}$ \\
\hline 0 & -78 & 6 & trace & - \\
& -25 & 6 & 11.7 & 87.5 \\
& 0 & 6 & 12.9 & 85.5 \\
& 40 & 6 & 36.0 & 86.5 \\
\hline 5.38 & 0 & 0.5 & 11.8 & 86.0 \\
& 20 & 0.5 & 40.0 & 88.0 \\
& 30 & 0.5 & 60.3 & 89.5 \\
& 40 & 0.5 & 70.6 & 88.0 \\
& 50 & 0.5 & 78.8 & 89.5 \\
\hline
\end{tabular}

a Solvent, toluene; $[\mathrm{M}] ; 0.48 \mathrm{~mol} l^{-1} ; A l / M$ molar ratio, 1.0 .

of $\mathrm{AlEt}_{2} \mathrm{Cl}$. Although the polymerization occurred with a moderate rate even in the absence of the free-radical initiator, the addition of this initiator induced a more rapid polymerization. The rate increased with an increase in the $A l / M$ molar ratio and reached a limiting value at an $A l / M$ molar ratio of 1.0 . Table $\mathrm{V}$ shows the effect of polymerization temperature. The polymerization slightly occurred even at $-78^{\circ} \mathrm{C}$ and the rate increased with a rise in temperature, especially in the presence of the radical initiator; however, the extent of cyclization was only slightly affected by temperature. Figure 3 shows 
that the extent of cyclization changes from 87.5 to $83 \%$ in the range of monomer concentration from 0.26 to $1.10 \mathrm{~mol}^{-1}$ and so the concentration dependence is less important.

Polymerization of o-Allylphenyl Acrylate in the Presence of $\mathrm{AlEtCl}_{2}$

The effect of $\mathrm{AlEtCl}_{2}$ molar content is shown in Table VI. The rate of polymerization was given the same effect by the addition of $\mathrm{AlEtCl}_{2}$ as in the case of $\mathrm{AlEt}_{1.5} \mathrm{Cl}_{1.5}$, but the extent of cyclization was still larger than that in the latter case. The rate increased with an increase in the

Table VI. Polymerization of $o$-allylphenyl acrylate in the presence of $\mathrm{AlEtCl}_{2}{ }^{\mathrm{a}}$

\begin{tabular}{llllcc}
\hline $\begin{array}{l}\text { [AIBN], } \\
\text { mmol } l^{-1}\end{array}$ & $\begin{array}{c}A l / M, \\
\text { Molar } \\
\text { ratio }\end{array}$ & $\begin{array}{c}{ }^{\circ} \mathrm{C} \text {, } \\
\text { rame }\end{array}$ & $\begin{array}{c}\text { Time } \\
\text { hr }\end{array}$ & $\begin{array}{c}\text { Conver- } \\
\text { sion, } \\
\%\end{array}$ & $\begin{array}{c}\text { Extent of } \\
\text { cycliza- } \\
\text { tion, } \%\end{array}$ \\
\hline 0 & 0.5 & 40 & 6 & 12.2 & 89.5 \\
& 0.75 & 40 & 6 & 15.9 & 89.5 \\
& 1.0 & 40 & 6 & 26.2 & 97.0 \\
& 1.25 & 40 & 6 & 23.4 & 99.0 \\
& 1.5 & 40 & 6 & 23.5 & 98.5 \\
& 1.75 & 40 & 6 & 18.9 & 96.0 \\
\hline 5.04 & 0.5 & 20 & 0.5 & 8.2 & 93.0 \\
& 0.75 & 20 & 0.5 & 17.5 & 97.0 \\
& 1.0 & 20 & 0.5 & 28.8 & 92.5 \\
& 1.25 & 20 & 0.5 & 29.6 & 95.0 \\
& 1.5 & 20 & 0.5 & 26.2 & 91.5 \\
\hline
\end{tabular}

- Solvent, toluene; [M], $0.45 \mathrm{~mol} l^{-1}$.

Table VII. Effect of temperature on the polymerization of $o$-allylphenyl acrylate in the presence of $\mathrm{AlEtCl}_{2}{ }^{\mathrm{a}}$

\begin{tabular}{lrrrc}
\hline $\begin{array}{c}\text { [AIBN], } \\
\text { mmol } l^{-1}\end{array}$ & $\begin{array}{c}\text { Temp, } \\
{ }^{\circ} \mathrm{C}\end{array}$ & $\begin{array}{c}\text { Time, } \\
\mathrm{hr}\end{array}$ & $\begin{array}{c}\text { Conversion } \\
\%\end{array}$ & $\begin{array}{c}\text { Extent of } \\
\text { cyclization, } \\
\%\end{array}$ \\
\hline 0 & -78 & 6 & 6.4 & 85.0 \\
& -25 & 6 & 18.7 & 94.5 \\
& 0 & 6 & 20.1 & 97.5 \\
& 40 & 6 & 30.3 & 99.0 \\
& 60 & 6 & 36.2 & 93.0 \\
& 80 & 6 & 36.6 & 92.5 \\
\hline 5.04 & 0 & 0.5 & 24.7 & 94.0 \\
& 20 & 0.5 & 28.8 & 92.5 \\
& 40 & 0.5 & 82.4 & 99.5 \\
\hline
\end{tabular}

a Solvent, toluene; [M], $0.45 \mathrm{~mol}^{l^{-1} ; A l / M \text { molar }}$ ratio, 1.0.
$A l / M$ molar ratio, went through a maximum at an $A l / M$ molar ratio of 1.0, and then decreased. The extent of cyclyzation scarcely changed with the $A l / M$ molar ratio gave a constant value, $96-99 \%$, at an $A l / M$ molar ratio of 1.0 or above. Table VII shows the effect of polymerization temperature. The polymerization occurred even at $-78^{\circ} \mathrm{C}$ and the rate increased with a rise in temperature. As shown in Figure 3, the extent of cyclization changed from 97 to $93 \%$ in the range of monomer concentration from 0.26 to $1.04 \mathrm{~mol} l^{-1}$. Consequently, the extent of cyclization is practically independent of the monomer concentration.

Effect of Added Alkylaluminum Chlorides on the Cyclopolymerization of o-Allylphenyl Acrylate

The IR spectra of polymers obtained in the presence of alkylaluminum chlorides are shown in Figure 4. In the presence of $\mathrm{AlEt}_{2} \mathrm{Cl}$ the extent of cyclization was larger than that in the case of the conventional radical polymerization, but was dependent upon the monomer concentration. The $k_{\mathrm{p}} / k_{\mathrm{c}}$ ratio estimated from the concentration was the same value in both cases. Therefore, the increase in the extent of cyclization can be best explained by assuming that the side reaction producing residual double bonds, such as the intramolecular chain transfer to the allyl group, was depressed by the action of

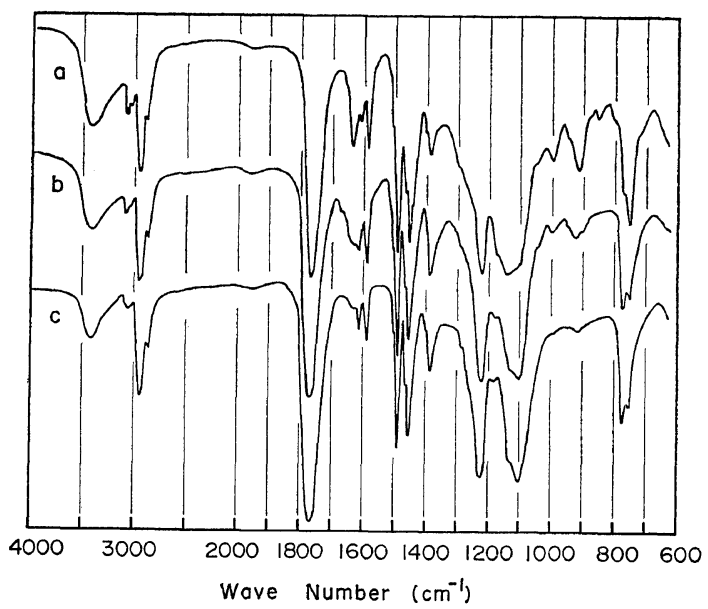

Figure 4. IR spectra of poly(o-allylphenyl acrylate) prepared: (a) in the presence of $\mathrm{AlEt}_{2} \mathrm{Cl}, f_{\mathrm{c}}=0.65$; (b) in the presence of $\mathrm{AlEt}_{1.5} \mathrm{Cl}_{1.5}, f_{c}=0.875$; (c) in the presence of $\mathrm{AlEtCl}_{2}, f_{c}=0.95$. 
$\mathrm{AlEt}_{2} \mathrm{Cl}$. It is known in homopolymerization ${ }^{10}$ and alternating copolymerization ${ }^{11}$ that the degradative chain transfer of allyl-type monomers is depressed by the addition of a Lewis acid. This behavior is strictly similar to that under investigation.

On the other hand, in the presence of $\mathrm{AlEt}_{1.5} \mathrm{Cl}_{1.5}$ and $\mathrm{AlEtCl}_{2}$ the rate of polymerization and the extent of cyclization were far larger than those in the case of $\mathrm{AlEt}_{2} \mathrm{Cl}$. In addition, the extent of cyclyzation was practically independent of the monomer concentration; this means that no competition between intramolecular cyclization and intermolecular linear propagation is involved in the reaction steps for the cyclopolymerization. The results suggest that there may be an intramolecular interaction between the acrylic double bond and the allylic double bond.

The cyclocopolymerization of $o$-allylphenyl acrylate with styrene was carried out so as to obtain information on the nature of the intramolecular interaction involved in the cyclopolymerization process. Figure 5 shows the result of the cyclocopolymerization in the presence of $\mathrm{AlEt}_{1.5} \mathrm{Cl}_{1.5}$. The compositions of the copolymers indicated that the copolymerization has a fairly alternating tendency. This tendency predicts that the electron donor monomer, styrene, may suppress the incorporation of the electropositive allylic double bond into the polymerization reaction by forming an intermolecular interaction with the electronegative acrylic double bond, so that the extent of

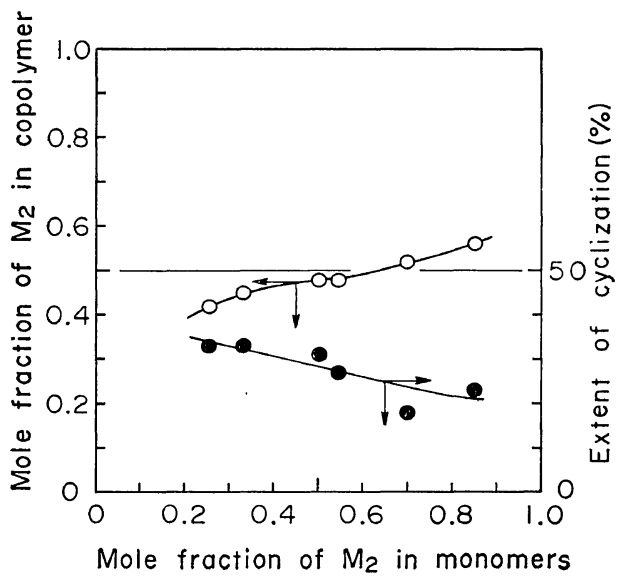

Figure 5. Variations of copolymer composition and the extent of cyclization with monomer feed in the system of $o$-allylphenyl acrylate $\left(\mathrm{M}_{1}\right)$-styrene $\left(\mathrm{M}_{2}\right)$ in the presence of $\mathrm{AlEt}_{1.5} \mathrm{Cl}_{1.5}:\left[\mathrm{M}_{1}\right], 0.45 \mathrm{~mol}$ $l^{-1} ; A l / M_{1}, 1.0$; temp, $40^{\circ} \mathrm{C}$.

cyclization may gradually decrease, approaching zero\% with increasing mole fractions of styrene. However, as shown in Figure 5, the experimental measurement shows an extent of cyclization of about $23 \%$ even at high mole fractions of styrene. This is interpreted as strong evidence for the presence of intramolecular interaction in the cyclopolymerization process.

Structure of the Cyclized Polymers Obtained in the Presence of Alkylaluminum Chlorides

In the cyclopolymerization of $o$-allylphenyl acrylate, there is the possibility of the formation

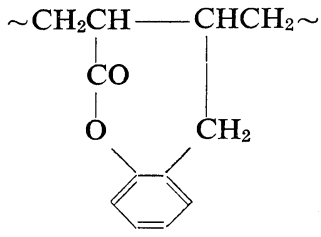

(I)

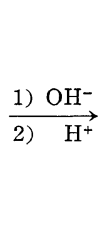

$\stackrel{\mathrm{OH}^{-}}{\stackrel{\mathrm{H}^{+}}{\longrightarrow}}$

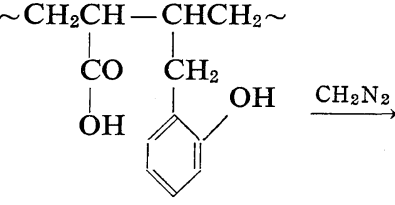

(II)<smiles>CCC(Cc1ccccc1OC)C(=O)OC</smiles>

(III)<smiles>CCC1CC2Cc3ccccc3OC(=O)C2C1</smiles>

(IV)

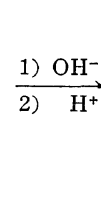

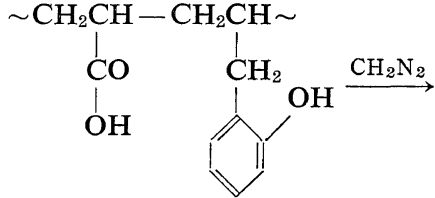

$(\mathbf{V})$<smiles>CCC(CCCC(=O)OC)Cc1ccccc1OC</smiles>

(VI) 
Cyclopolymerization in the Presence of $\mathrm{AlEt}_{n} \mathrm{Cl}_{3-n}$. I.

Table VIII. Copolymerization of methyl acrylate $\left(\mathrm{M}_{1}\right)$ and $o$-methoxyallylbenzene $\left(\mathrm{M}_{2}\right)$ in the presence of $\mathrm{AlEt}_{1.5} \mathrm{Cl}_{1.5}$ and $\mathrm{AlEtCl}_{2}{ }^{\mathrm{a}}$

\begin{tabular}{ccccccc}
\hline $\begin{array}{c}\mathrm{AlEt}_{n} \mathrm{Cl}_{3-n}, \\
\mathrm{mmol}\end{array}$ & $\begin{array}{c}{\left[\mathrm{M}_{1}\right],} \\
\mathrm{mmol}\end{array}$ & $\begin{array}{c}{\left[\mathrm{M}_{2}\right],} \\
\text { mmol }\end{array}$ & $\begin{array}{c}M_{1}, \\
\text { Mole fraction } \\
\text { in monomers }\end{array}$ & $\begin{array}{c}\text { Time, } \\
\mathrm{hr}\end{array}$ & $\begin{array}{c}\text { Yield, } \\
\mathrm{mg}\end{array}$ & $\begin{array}{c}m_{1}, \\
\text { Mole fraction } \\
\text { in copolymer }\end{array}$ \\
\hline $\mathrm{AlE}_{1.5} \mathrm{Cl}_{1.5}$ & & & & & & \\
3.55 & 3.60 & 12.99 & 0.217 & 1.0 & 159 & 0.450 \\
& 3.52 & 6.58 & 0.349 & 1.5 & 206 & 0.498 \\
& 3.57 & 3.40 & 0.512 & 2.0 & 181 & 0.505 \\
& 3.48 & 1.86 & 0.652 & 3.0 & 128 & 0.550 \\
& 3.64 & 0.83 & 0.814 & 17.0 & trace & - \\
\hline $\mathrm{AlEtCl}_{2}$ & & & & & & \\
3.55 & 3.65 & 13.38 & 0.214 & 2.0 & 357 & 0.461 \\
& 3.64 & 6.83 & 0.348 & 2.0 & 332 & 0.472 \\
& 3.90 & 3.36 & 0.537 & 2.0 & 189 & 0.490 \\
& 3.56 & 1.81 & 0.663 & 4.0 & 92 & 0.538 \\
& 3.55 & 0.69 & 0.837 & 15.0 & trace & - \\
\hline
\end{tabular}

a Solvent, toluene, $1.5 \mathrm{ml}$; AIBN, $0.30 \mathrm{mmol}$; temp, $40^{\circ} \mathrm{C}$.

of polymers containing seven- and eightmembered rings, as indicated in (I) and (IV). In order to clarify the cyclic structure of polymers obtained in the presence of alkylaluminum chlorides, the polymers were hydrolyzed and then the hydrolyzed polymers were treated with diazomethane, as shown in eq 3 and 4 . The structures indicated in (III) and (VI) correspond to a head-to-head and a head-to-tail

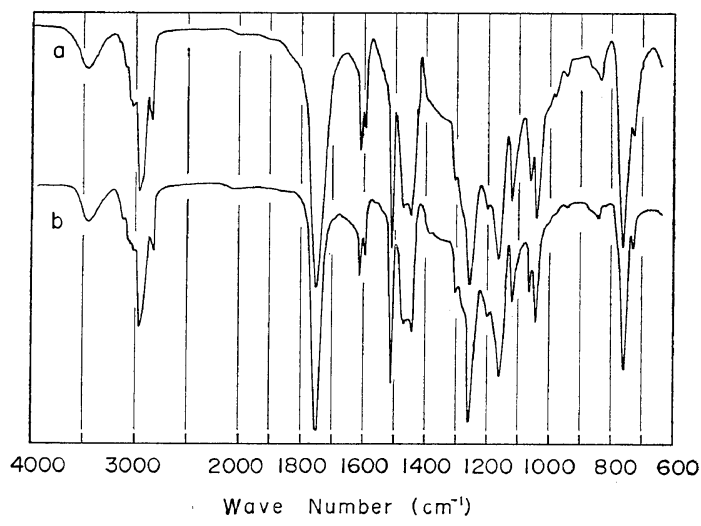

Figure 6. IR spectra of (a) the polymer derived from the poly(o-allylphenyl acrylate), $f_{c}=0.95$, by hydrolysis and treatment with diazomethane, and (b) the alternating copolymer prepared from the system of methyl acrylate- $o$-methoxyallylbenzene with $1: 1$ molar ratio in feed, in the presence of $\mathrm{AlEt}_{1.5} \mathrm{Cl}_{1.5}$. bonding in the alternating copolymer of methyl acrylate and $o$-methoxyallylbenzene. The alternating copolymer actually obtained seems to have head-to-tail bondings, in common with other alternating copolymers. ${ }^{12}$

The copolymerization of methyl acrylate and $o$-methoxyallylbenzene was carried out in the presence of $\mathrm{AlEt}_{1.5} \mathrm{Cl}_{1.5}$ and $\mathrm{AlEtCl}_{2}$. The results are shown in Table VIII. The compositions of the copolymers determined from the relative area of the absorptions in the NMR spectrum show that the copolymerization has a fairly alternating tendency. The IR spectrum of the material derived from the cyclized polymer was compared with that of the copolymer obtained with a 1:1 molar ratio in feed. As shown in Figure 6, the former has IR absorption characteristics identical to those of the latter, except that the absorption bands are slightly broadened. It is concluded that $o$-allylphenyl acrylate polymerized to give polymers containing eight-membered rings by a cyclic mechanism.

\section{REFERENCES}

1. O. F. Solomon, M. Corciovei, and V. Tărărescu, J. Appl. Polym. Sci., 11, 1631 (1967).

2. O. F. Solomon, M. Corciovei, and E. Beral, $J$. Polym. Sci., Part B, 6, 507 (1968).

3. O. F. Solomon, M. Corciovei, I. Gabe, and E. Beral, ibid., Part A-1, 9, 509 (1971). 
K. Yokota, N. Hirayama, and Y. Takada

4. M. Hirooka, H. Yabuuchi, S. Morita, S. Kawasumi, and K. Nakaguchi, ibid., Part $B$, 5, 47 (1967).

5. S. Yabumoto, K. Ishii, and K. Arita, ibid., Part $A-1,7,1577$ (1969).

6. T. Ikegami and H. Hirai, ibid., Part $A-1,8$, 463 (1970).

7. S. Ota, Bunseki Kagaku (Japan Analyst), 18, 1257 (1969).

8. A. Katchalsky and H. Eisenberg. J. Polym. Sci., 6, 145 (1950).
9. J. Roovers and G. Smets, Makromol. Chem., 60, 89 (1963).

10. V. P. Zubov, M. B. Lachinov, V. B. Golubev, V. F. Kulikova, V. A. Kabanov, L. S. Polak, and V. A. Kargin, J. Polym. Sci., Part C, 23, 147 (1968).

11. M. Hirooka, H. Yabuuchi, S. Kawasumi, and K. Nakaguchi, ibid., Polym. Chem. Ed., 11, 1281 (1973).

12. F. Shepherd and H. J. Harwood, ibid., Part B, 9, 419 (1971). 